\begin{tabular}{|c|c|c|}
\hline & Postgraduate Bosowa University Publishing (PBUP) & ONESIAN \\
\hline & $\begin{array}{l}\text { Indonesian Journal of Business and Management } \\
\text { e-ISSN: } 2460-3767 \quad p \text {-ISSN: } 2656-6885\end{array}$ & \\
\hline 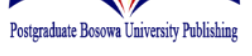 & https://postgraduate.universitasbosowa.ac.id/index.php/jbm & $\begin{array}{l}\text { OF BUSINESS } \\
\text { NO MANAGEMENT }\end{array}$ \\
\hline
\end{tabular}

\title{
PENGARUH PENERAPAN TEKNOLOGI INFORMASI TERHADAP KINERJA PEGAWAI DAN KEMAMPUAN PENGGUNA SEBAGAI VARIABEL MODERASI DI KANTOR KECAMATAN MALILI
}

\author{
The Effect of the Implementation of Information Technology on Employee Performance and User \\ Capability as a Moderator Variabel at District Office of Malili
}

\author{
Muhammad Ainul Haeruddin', Sukmawati Marjuni ${ }^{2}$, Herminawati $^{2}$ \\ ${ }^{1}$ Pemerintahan Kota Kendari Sulawesi Tenggara \\ ${ }^{2}$ Program Studi Manajemen Program Pascasarjana Universitas Bosowa
}

Email: ainulhaeruddin@yahoo.com

Diterima: 20 Agustus 2020 /Disetujui: 07 Desember 2020

\begin{abstract}
ABSTRAK
Manajemenosumber daya manusiaOmerupakan bagian dariOilmu manajemen yangOberarti suatu usaha untuk mengarahkan dan mengelola sumber daya manusiaodalam suatuoorganisasi agar mampu berpikirOdan bertindak sebagaimanaoyang diharapkan0organisasi. Tujuan dari penelitian ini adalah mengujiOpengaruh penerapanoteknologi informasi terhadapOkinerja pegawaiOdengan kemampuan penggunaOsebagai variabel moderasiOpada Kantor Kecamatan Malili. TeknikOpengumpulan data melaluiOobservasi, interview dan dokumentasi serta kuesioner, sedangkanOteknik analisis dataoyangOdigunakan adalahoanalisis analisisodeskriptif, ujiOvaliditas dan reliabilitas, uji asumsioklasik, analisis regresiOlinear bergandaoserta pengujianohipotesis. Hasil penelitian_menemukan bahwaOpenerapan teknologi_informasi berpengaruh_positif dan signifikanOterhadap kinerjaOpegawai, kemampuan pengguna berpengaruh_positif danOsignifikan terhadapOkinerja pegawai, sertaOkemampuan pengguna sebagaiOvariable moderasiOmampu memoderasiOpengaruh penerapanOteknologi informasi terhadapOkinerja pegawai kantor Kecamatan Malili.
\end{abstract}

Kata Kunci: Penerapan Teknologi Informasi, Kemampuan Pengguna, Kinerja Pegawai, Variabel Moderasi

\begin{abstract}
Human resource management is an effort to direct and manage human resources in an organization to be able to think and act as expected by the organization. The purpose of this research is to examine the effect of information technology implementation on employee performance with user ability as a moderator variable at the Malili District Office. Data collection techniques through_observation, interviews, documentation and questionnaires, while the data analysis techniques used are descriptive analysis, validity and reliability, classical assumption test, multiple_linear regression analysis and hypothesis testing. The results showed that the implementation of information technology has a positive and significant effect on employee performance, the user ability has a positive and significant effect on employee performance, and the user ability as a moderator variable is able to moderate the effect of the information technology implementation on employee performance.
\end{abstract}

Keywords: Information Technology Implementation, Employee-Performance, User Ability, Moederator Variables

\section{PENDAHULUAN}

Dalam organisasi, sumber daya manusia merupakanohuman capital karena dianggap mampu memberikanokontribusi terhadap profitabilitas. Sumber daya manusia juga dapat juga dikatakan sebagai modal intelektual (intelectual capital), sebab kemampuan memberikan ide-ide cemerlang dalam pengembangano organisasi. Dalam mengembangkan suatu organisasi tidak lepas dengan tuntutan untuk bagaimana melakukan proses pekerjaan dengan cepat dan terukur untuk mendapatkan suatu tujuan yang ingin dicapai organisasi, salah satu 
aspek adalah penggunaanoteknologi informasi dalam suatuoorganisasi. Penggunaan teknologi diharapkan mampu menunjukkan perubahan yang signifikan pada aspek kinerja, sehingga laju pertumbuhan organisasi kian pesat. Selain itu, adanya sikap optimisme dalam memandang perubahan menjadi salah satu modal dasar dalam menciptakan sumber daya manusia yang unggul (Alim \& Rakhmat, 2020).

Teknologi Informasi (TI) merupakan suatu yang bisa dikatakan jenis teknologi yang berbentuk peralatanoteknis dan berfungsi untuk menyampaikan dan memperoses informasi. Teknologi informasiotermasuk peralatanperalatan yang berfungsi sebagai alat untuk memdapatkan suatu informasi atau memperoses data-data, alat manipulasi, alat bantu dan alat pengelolaan informasi. di era globalisasi ini teknologi informasi mengalami perubahan dan perkembangan yang sangat signifikan, hal tersebut dapat di lihat dengan peralatan teknologi yang memiliki jangkauan yang luas dan semakin canggih. Dengan kemajuanoteknologi informasi maka kegiatan yang dilakukan oleh pengguna atau sumber daya manusia dapat terselesaikan secara lebih efisien dan efektif sertaomendapatkan hasil yang di inginkan. Teknologi Informasi telah berkembang dengan pesat pada era saat ini, dapat dilihat dari seiring meningkatnya kebutuhan masyarakat terhadap pelayanan yang cepat dan tepat sehingga banyak dari berbagai pihak-pihak swasta maupun negeri yang menggunakan teknologi informasi sebagai suatu proses pelayanan kepada masyarakat saat ini (Afdaliana, at.al, 2019).

Penerapan teknologi informasi didalam sebuah instansi pemerintah harus didukung dengan kemampuan SDM atau penggunanya yang kompeten dalam mengaplikasikan teknologi informasi, Begitupun didalam suatu pemerintahan daerah Pegawai Negeri Sipil (PNS) selain dituntut untuk mengembangkan ilmu terapan tentang suatu tupoksinya masing-masing Pegawai Negeri Sipil (PNS) juga di tuntut untuk dapat menggunakan teknologi dalam hal suatu proses pelayanan publik, Hal iniodikarenakan yang menggunakan teknologi informasi adalah sebagian besar yaitu sumber daya manusia yang ada di lingkungan pemerintahan daerah, untuk itu sangat perlu diperhatikan kemampuan-kemampuan pengguna dalam menggunakan teknologi informasi yang digunakan. Disatu sisi kualitas kerja juga menjadi salah salah satu faktor utama yang berpengaruh dan sangat penting terhadap keberhasilan pegawai negeri dalam melaksanakan tupoksinya. Kemampuan dapat diartikan sebagai suatu hasil kerja yang dilakukan oleh pegawai dalam menyelesaikan pekerjaannya yang diukur berdasarkan pengalaman, kecakapan dan keseriusan dalam bekerja.

Peraturan Bupati Luwu Timur Nomor 47 Tahun 2017 tentang pemanfattan teknologi informasi danokomunikasi dalam pengembangan $e$ governmentodilingkungan Pemerintah Kabupaten Luwu Timur, Teknologi informasi dan komunikasi dapat diartikan sebagai suatu kegiatan yang terkait dengan pengelolaan, pemprosesan dan penyampaian atau pemindahan informasioantar sarana/media, Sebagai media yang menyalurkan informasi, Teknologi Informasi dan Komunikasi dalam perkembangannya sangat mempengaruhi segala bidang-bidang, salah satunya adalah bidang pemerintahan. Teknologi IT dalam pemerintahan merupakan sebuah terobosan baru dalam hal pengelolaan dan penyebaran informasi mengenai pemerintahan kepada masyarakat. Dengan adanya teknologi yang diterapkan dalam sebuah pemerintahan diharapkan dapat memberi kemudahan dan transparansi publik serta penyelesaian pekerjaan yang semakin kompleks (Dewi, 2015).

Kantor Kecamatan Malili saat ini baru-baru saja menggunakan atau menerapkan sistem terpadu yang berbasis IT dengan harapan dapat mengembangkan dan memajukan kinerja pegawai dan dapat memuaskan suatu proses pelayananomasyarakat yangodiberikan, dengan adanya hal tersebut sehingga peneliti tertarik mengambil variabel teknologi informasi dalam penelitian. Di sebuahoartikel dalam website kecamatan malili menyebutkan bahwa "kecamatan malili telah mengembangkanoaplikasi e-office dan situs website yang bisa digunakan sebagai pengaduan kepada seluruh masyarakat kecamatan malili. Dengan aplikasioini masyarakat tidak perluodatang ke kantor untuk mendapatkan pelayanan pengaduan dan perizinan hanya dengan mengisi data formulir yang tersedia di situs yang telah ditentukan dan melengkapi berkas-berkas yang di butuhkan. Harapanoitulah yang menjadi alasan peneliti memilihovariabel kinerja pegawai dan sudah0dibuktikan dengan penelitianosebelumnya sebelumnya bahwa terjadi hubungan yang positif antara penerapan teknologi informasi dengan_kinerja pegawai.

\section{METODE PENELITIAN}

\subsection{Jenis Penelitian}

Penelitian yang digunakan peneliti yaitu menggunakan penelitian dengan metode kuantitatif. Penelitian kuantitatif yaitu salah satu jenis penelitian yang pada dasarnya menggunakan pendekatan deduktifinduktif. Pendekatan ini berangkat dari sutau gagasan para ahli dan kerangka teori, juga pemahaman-pemahaman peneliti berdasarkan pengalamannya, kemudian menjadi permasalahan-permasalahan yang dikembangkan dan dicari pemecahannya yang diajukan untuk memperoleh pembenaran (verifikasi) atau penilaian dalam bentuk dukungan data empiris dilapangan. Sugiyono (2014:6) selain itu dalam penelitian ini juga menggunakan metode survey, yaitu metode yang digunakan untuk memperoleh data dari tempat tertentu yang alamiah dan penelitian melakukan pengumpulan data melalui observasi, dokumentasi, penyebaran kuisioner dan wawancara (Ghozali, 2012).

\subsection{Lokasi Penelitian}

Fokus penelitin ini dilakukan di Kantor Kecamatan Malili Pemerintah Kabupaten Luwu Timur Provinsi Sulawesi Selatan yang terletak di Jl.Dr.Ratulangi No.4. 


\subsection{Populasi dan Sampel}

Wilayah generalisasi-yang terdiri atas-objek/subjek yang mempunyai kualiti dan karakter tentang apa yang di pilih oleh peneliti untuk mempelajari dan kemudian menarik kesimpulan dapat dikatan sebagai populasi. Berdasarkan hal tersebut dapat diambil batasan pengertian bahwa populasi juga dapat dikatakan sebagai keseluruhan objek atau unsur sebagai sumber data dengan karakteristik tertentu dalam sebuah penelitian. Untuk itu peneliti mengambil suatu populasi dari seluruh pegawai di Kantor Kecamatan Malili Kabupaten Luwu Timur yang berjumlah 45 orang. Sedangkan untuk menentukan sampel harus dipilih yang benar-benar sesuai melalui teknik-teknik pengambilan sampel (sampling) agar dapat diperoleh sampel yang benar-benar dapat mewakili (representatife) dari jumlah populasi yang sebenarnya. Penelitian ini menggunakan sampel seluruh pegawai yang berada di Kantor Kecamatan Malili sebanyak 45 orang yang memanfaatkan penerapan Teknologi Informasi dalam menjalankan pekerjaannya. Sugiyono (2014:84) dalam penelitian ini menggunakan teknik pengambilan sampel Non Probability Sampling adalah teknik pengambilan sampel yang tidak memberi kesempatan atau peluang yang sama bagi setiap anggota atau unsur populasi untuk dipilih menjadi sampeldengan metode sampling jenuh, yaitu teknik pengambilan sampel dengan cara mengambil seluruh jumlah populasi untuk dijadikan sampel tanpa terkecuali yang terdapat pada objek penelitian, sehingga dalam penelitian ini hasilnya menunjukkan jumlah sebanyak 45 pegawai.

\subsection{Variabel Penelitian}

Variabel dalam penelitian ini dibagi menjadi tiga, yaitu: Variabel terikat, Variabel bebas dan Variabel Moderasi yang ini meliputi: a. Teknologi informasi (X), b. Kinerja Pegawai $(\mathrm{Y})$ dan c. Kemampuan Pengguna (M).

\subsection{Teknik Pengumpulan Data}

Teknik pengumpulan data yaitu cara-cara yang dilakukan untuk memperoleh data dan keterangan keterangan yang diperlukan dalam penelitian. Adapun instrumen yang digunakan dalam penelitian gunakan yaitu pedoman observasi, pedoman angket dan pedoman dokumentasi:

a. Observasi, Peneliti-terlebih dahulu melakukan survei dan menentukan tempat, dalam hal penelitian ini yaitu pada Kantor Kecamatan Malili Kabupaten Luwu Timur.

b. Pedoman Angket, Alat bantu berupa pernyataan yang harus dijawab oleh responden. Pada penyusunan angket peneliti membuat kisi-kisi dan pedoman penskoran Instrumen angket adalah instrumen utama dalam penelitian ini. Mengingat data penelitian merupakan aspek yang penting dalam penelitian, sehingga instrumen atau alat yang digunakan mengukur harus terpercaya.

c. Dokumentasi, Alat bantu yang digunakan oleh peneliti untuk mengumpulkan data-data, dan arsip-

\author{
arsip dokumentasi.
}

\subsection{Jenis dan Sumber Data}

Penelitian ini menggunakan jenis-jenis data yaitu:

a. Data Kualitatif merupakan data yang tidak berupa angka dan tidak dinyatakan dalam satuan hitung tertuntu melainkan dalam bentuk kalimat yang merupakan pertanyaan presepsi responden.

b. Data kuantitatif adalah data berupa angka dan dinyatakan dalam satuan hitung tertentu. Dalam penelitian ini yang termasuk data kuantitatif seperti nilai penjualan, serta data lainnya yang menunjang pokok pembahasan ini.

Sedangkan sumber data yang digunakan dalam penelitian ini yaitu:

a. Data Primer

Data primer yang bersumber dari objek yang diamati, dalam hal ini adalah responden yang di beri koesioner.

b. Data Sekunder

Data sekunder adalah data yang di peroleh bersumber dari laporan dan dokumentasi Kecamatan Malili.

\subsection{Teknik Analisis Data}

Dari hasil penelitian yang-dikumpulkan maka selanjutnya akan dapat disajikan analisis terhadap masalah yang dihadapi dengan menggunakan analisis kuantitatif yaitu sebagai berikut:

a. Uji Instrumen

1. Uji Validitas

Untuk uji Validitas, dapat dilakukan dengan perhitungan korelasi antara masing-masing item pertanyaan dengan skor total. Item yang mempunyai korelasi positif dengan skor total serta korelasi yang tinggi menunjukkan bahwa item tersebut memiliki validitas yang tinggi pula. Biasanya syarat minimal untuk dianggap memenuhi syarat adalah jika $r_{\text {kitis }}=0,3$. Jadi, jika korelasi antara butir dengan skor total kurang dari 0,3 maka butir dalam instrument tersebut dinyatakan tidak valid (Masrun, 1979 dalam sugiono, 2013).

2. Uji Reliabilitas

Pengujian reabilitas dimaksudkan untuk mengetahui apakah kuesioner dapat memberikan ukuran yang konstan atau tidak. Instrument yang handal berarti mampu mengungkapkan data yang dapat dipercaya. Pengujian reliabilitas dilakukan dengan menggunakan teknik belah dua ganjil genap, dimana penelitian dilakukan dengan mengelompokkan skor butir genap sebagai belahan kedua.

b. Uji Asumsi Klasik

1. Uji Normalitas

Pengujian ini dilakukan untuk mengetahui apakah analisis dalam model regresi nilai residual memiliki distribusi normal. Pada penelitian ini alat uji statistik menggunakan KolmogrovSmirnov dengan melihat nilai signifikasi variabel, jika signifikan lebih besar a $=5 \%$ maka menunjukkan distribusi data normal. 
2. Uji Multikolinearitas

Pengujian ini dilakukan untuk mengetahui korelasi antar variabel independen. Pada penelitian ini menggunakan alat statistik Variances Inflation Factor (VIF). Nilai tolerance yang rendah sama artinya dengan nilai VIF yang tinggi. Jika nilai tolerance lebih besar dari 0,1 dan nilai VIF lebih kecil dari 10 serta nilai matriks korelasi tidak ada yang lebih besar dari 0,5, maka tidak terjadi multikolinieritas.

3. Uji Heteroskedastisitas

Pengujian ini dilakukan untuk menguji apakah_dalam model regresi_terjadi ketidaksamaan varians dari residual satu pengamatan ke pengamatan yang lain. Jika terdapat kesamaan atau tetap disebut homoskedastisitas dan jika berbeda disebut heteroskedastisitas. Pada-penelitian ini alat uji statistiknya menggunakan uji glejser dengan meregresikan variabelvariabel independen-terhadap nilai absolute residualnya.

4. Uji Autokorelasi

Uji autokorelasi dilakukan untuk mengkorelasikan antar anggota observasi yang disusun menurut waktu dan tempat. Dalam penelitian ini uji autokorelasi dilakukan dengan metode Uji Run dengan melihat nilai AsympSig (2-tailed) harus lebih besar 0,05. Model regresi yang baik seharusnya tidak terjadi autokorelasi.

c. Analisis Regresi

Untuk hipotesis pertama dan kedua digunakan alat uji dengan metode regresi linear sederhana untuk menentukan ketetapan prediksi dari pengaruh yang terjadi antara variabel independen terhadap variable dependen.

$$
\mathrm{Y}=\mathrm{b} 0+\mathrm{bX}+\mathrm{e}
$$

Untuk hipotesis ketiga digunakan alat uji interaksi dengan menggunakan MRA metode regresi linear berganda

$$
\mathrm{Y}_{0}=\mathrm{a}+\mathrm{b}_{1} \mathrm{X}+\mathrm{b}_{2} \mathrm{M}+\mathrm{b}_{3} \mathrm{X}-\mathrm{M}+\mathrm{e} . .(\text { persamaan } 2) .
$$

d. Uji Hipotesis

1. Uji Parsial (Uji t)

Uji $\mathrm{T}$ dilakukan dengan cara membandingkan antara nilai t hitung yang didapatkan dari hasil olah data SPSS 21 dengan nilai $\mathrm{t}$ tabel yang didapatkan dari Microsoft Excel dengan menggunakan rumus TINV. Tingkat signifikasi lebih $<0,05$.

\section{Uji F (Moderasi)}

Uji F dilakukan untuk menguji signifikansi antara variabel-variabel bebas dan variabel terikat secara keseluruhan. Untuk mendapatkan hasil yang menyakinkan maka akan dilakukan pengujian dengan tingkat signifikansi 0.05 atau 5\%. Apabila dari perhitungan diperoleh probabilitas $<0,05$

3. Uji T (Moderasi)

Statistik-uji T disebut juga sebagai uji signifikansi parsial. Uji ini menunjukkan seberapa jauh pengaruh variabel independen secara parsial terhadap variabel dependen.

4. Menentukan koefisien determinasi $\left(\mathrm{r}^{2}\right)$

Koefisien determinasi digunakan untuk mengetahui seberapa besar pengaruh teknologi informasi terhadap kinerja pegawai dengan kemampuan pengguna sebagai variabel moderasi. Adapun koefesien determinasi yang dihasilkan oleh model regresi ditunjukkan oleh nilai $\mathrm{R}$ Square pada analisis regresi moderasi dengan bantuan program SPSS 21.

\section{HASIL DAN PEMBAHASAN}

Untuk mengetahui pengaruh Teknologi informasi, kemampuan pengguna terhadap kinerja pegawai pada Kantor Kecamatan Malili Kabupaten Luwu Timur, Dimana dalam melakukan pengujian dalam penelitian ini maka digunakan analisis regresi linear sederhana, dengan menggunakan SPSS 21 yang dapat disajikan pada tabel berikut ini:

Tabel 1. Hasil Analisis Regresi Linear teknologi informasi terhadap kinerja pegawai

\begin{tabular}{c|r|r|c|r|l}
\hline \multirow{2}{*}{ Model } & \multicolumn{2}{|c|}{$\begin{array}{c}\text { Unstandardized } \\
\text { Coefficients }\end{array}$} & $\begin{array}{c}\text { Standardized } \\
\text { Coefficients }\end{array}$ & \multirow{2}{*}{$\mathrm{T}$} & \multirow{2}{*}{ Sig. } \\
\cline { 2 - 4 } & \multicolumn{1}{c|}{$\mathrm{B}$} & Std. Error & Beta & & \\
\hline 1 (Constant) & .357 & .209 & & 1.706 & .095 \\
Teknologi & .894 & .054 & .929 & 16.49 & .000 \\
Informasi & \multicolumn{3}{|c|}{. } & &
\end{tabular}

Tabel 2. Hasil Analisis Regresi Linear Kemampuan Pengguna Terhadap Kinerja Pegawai

\begin{tabular}{c|c|c|c|c|c}
\hline \multirow{2}{*}{ Model } & \multicolumn{2}{|c|}{$\begin{array}{c}\text { Unstandardi } \\
\text { Coefficients }\end{array}$} & $\begin{array}{c}\text { Standardized } \\
\text { Coeffi }\end{array}$ & \multirow{2}{*}{$\mathrm{T}$} & \multirow{2}{*}{ Sig. } \\
\cline { 2 - 4 } & $\mathrm{B}$ & $\begin{array}{c}\text { Std. } \\
\text { Error }\end{array}$ & Beta & & \\
\hline $\begin{array}{c}\text { 1. (Constant) } \\
\text { kemampuan } \\
\text { pengguna }\end{array}$ & .624 & .238 & & 2.616 & .012 \\
\hline Sumber $:$ Data Dion & .845 & .063 & .898 & 13.353 & .000 \\
\hline
\end{tabular}

Sumber : Data Diolah dari SPSS

Berdasarkan Tabel 1 menujukkan bahwa t hitung>t table Dimana nilai t hitung untuk Teknologi Informasi (X1) sebesar 16.499 sedangkan t table sebesar 2.014 tingkat signifikan $0,000<$ tingkat kepercayaan $5 \%(0,05)$ maka dapat dinyatakan penelitian ini menerima $\mathrm{Ha}$ bahwa secara parsial teknologi informasi berpengaruh dan signifikan terhadap kinerja pegawai.

Tabel 2, menujukkan bahwa t hitung $>$ t table Dimana niali t hitunguntuk Kemampuan pengguna (X2) sebesar 13.353sedangkan t table sebesar 2.014 tingkat signifikan $0,000<$ tingkat kepercayaan $5 \%(0,05)$ maka dapat dinyatakan penelitian ini menerima Ha bahwa secara parsial kemampuan pengguna berpengaruh dan signifikan terhadap kinerja pegawai.

Hasil Analisis Regresi Linear Berganda dapat dilihat pada tabel di bawah ini.

\begin{tabular}{|c|c|c|c|c|c|}
\hline Model & $\begin{array}{l}\text { Sum of } \\
\text { Squares }\end{array}$ & Df & $\begin{array}{c}\text { Mean } \\
\text { Square }\end{array}$ & $\mathrm{F}$ & Sig. \\
\hline 1 Regression & 24.440 & 3 & 8.147 & 140.928 & $.000 \mathrm{~b}$ \\
\hline Residual & 2.370 & 41 & .058 & & \\
\hline Total & 26.810 & 44 & & & \\
\hline
\end{tabular}

Tabel 3. Uji F (Moderasi) 
b. Predictors: (Constant), Moderasi, Penerapan teknologi informasi,

Kemampuan pengguna

Berdasarkan Tabel 3, ditunjukkannilai f hitung adalah 140.928 dan nilai $\mathrm{f}$ tabel yang didapatkan menggunakan rumus excel adalah 2,014 dapat dikatakan bahwa $\mathrm{f}_{\text {hitung }}>\mathrm{f}_{\text {tabel }}$ dan nilai signifikan table anova $=0,000$ lebih kecil dari 0,05 sehingga dapat dikatakan bahwa secara bersama-sama variabel-variabel (penerapan teknologi infromasi dan kemampuan pengguna) beserta variabel moderasi berpengaruh secara signifikan terhadap variabel dependen yaitu kinerja pegawai.

Tabel 4. Uji T (Moderasi)

\begin{tabular}{|c|c|c|c|c|c|}
\hline \multirow{2}{*}{ Model } & \multicolumn{2}{|c|}{$\begin{array}{c}\text { UnstandardizeCo } \\
\text { efficients }\end{array}$} & \multirow{2}{*}{$\begin{array}{c}\begin{array}{c}\text { StandardizeC } \\
\text { oefficients }\end{array} \\
\text { Beta }\end{array}$} & \multirow{2}{*}{$\mathrm{t}$} & \multirow{2}{*}{ Sig. } \\
\hline & B & $\begin{array}{l}\text { Std. } \\
\text { Error }\end{array}$ & & & \\
\hline (Constant) & 2.180 & .506 & & 4.309 & .000 \\
\hline $\begin{array}{l}\text { Teknologi } \\
\text { Informasi }\end{array}$ & 1.216 & .284 & 1.263 & 4.287 & .000 \\
\hline $\begin{array}{l}\text { Kemampuan } \\
\text { Pengguna }\end{array}$ & 1.602 & .355 & 1.701 & 4.518 & .000 \\
\hline Moderasi & .197 & .049 & 1.367 & 4.018 & .000 \\
\hline
\end{tabular}

a. Dependent Variable: Kinerja Pegawai

Berdasarkan Tabel 4 diatas maka dapat diperoleh persamaan sebagai berikut:

$$
\mathrm{Y}=2.180+1.216+1.602+0.197 \mathrm{X} 1 * \mathrm{X} 2+\mathrm{e}
$$

Dari hasil analisis multiplier regression, maka hasil interpretasinya dapat dijabarkan sebagai berikut bahwa nilai $b_{0}=2.180$, hal ini menunjukkan bahwa pada penerapan teknologi informasi, kemampuan pengguna maka secara langsung akan berpengaruh terhadap peningkatan kinerja pegawai kantor kecamatan malili.Untuk nilai $b_{1}=1,216$ yang menunjukkan koefisien regresi variabel penerapan teknologi informasi (X1) artinya jika skor tanggapan responden mengenai penerapan teknologi informasi ditingkatkan maka akan berpengaruh positif terhadap kinerja pegawai, kemudian nilai $b_{2}=1,602$ yang menujukkan koefisien regresi variabel kemampuan pengguna artinya jika skor tanggapan responden mengenai kemampuan pengguna ditingkatkan maka akan berpengaruh positif terhadap kinerja pegawai, sedangkan untuk nilai $b_{3}=0,197$ yang merupakan koefisien regresi variabel moderasi kemampuan pengguna artinya jika tanggapan responden mengenai kemampuan pengguna sebagai variable moderasi ditingkatkan maka akan berpengaruh positif terhadap kinerja pegawai.

Hasil perhitungan Koefisien Determinasi $\left(r^{2}\right)$ dapat dilihat pada tabel di bawah ini.

Tabel 5. Koefisien Determinasi Sebelum Moderasi

\begin{tabular}{c|c|c|c|c|c}
\hline Model & $\mathrm{R}$ & $\begin{array}{c}\mathrm{R} \\
\text { Square }\end{array}$ & $\begin{array}{c}\text { Adjusted } \\
\text { R Square }\end{array}$ & $\begin{array}{c}\text { Std. Error of } \\
\text { the Estimate }\end{array}$ & $\begin{array}{c}\text { Durbin- } \\
\text { Watson }\end{array}$ \\
\hline 1 & $.929 \mathrm{a}$ & .864 & .860 & .292 & 1.864 \\
\hline
\end{tabular}

a. Predictors: (Constant), Teknologi informasi

b. Dependent Variable: kinerja pegawai
Berdasarkan tabel 5 di atas diperoleh nilai Adjusted R Square sebesar 0,860. Maka nilai koefisien determinasi karena adanya teknologi informasi dan kemampuan pengguna adalah sebesar 86,0\%. Dapat disimpulkan bahwa kinerja pegawai dipengaruhi oleh teknologi informasi dan kemampuan pengguna sebesar 86,0\%, sedangkan sisanya sebesar $14.0 \%$ dijelaskan oleh faktorfaktor lain yang tidak dimasukkan ke dalam penelitian ini.

Tabel 6. Koefisien Determinasi Setelah Moderasi

\begin{tabular}{l|c|r|r|r|r}
\hline Model & $\mathrm{R}$ & $\begin{array}{c}\mathrm{R} \\
\text { Square }\end{array}$ & $\begin{array}{c}\text { Adjusted R } \\
\text { Square }\end{array}$ & $\begin{array}{c}\text { Std. Error of } \\
\text { the Estimate }\end{array}$ & $\begin{array}{r}\text { Durbin- } \\
\text { Watson }\end{array}$ \\
\hline 1 & $.955^{\mathrm{a}}$ & .912 & .905 & .240 & 1.901 \\
\hline \multicolumn{2}{l}{$\begin{array}{l}\text { a. Predictors: (Constant), Moderasi, teknologi informasi, kemampuan } \\
\text { pengguna } \\
\text { b. Dependent Variable: kinerja pegawai }\end{array}$}
\end{tabular}

Berdasarkan Tabel 6 diatas diperoleh nilai Adjusted R Square sebesar 0,905. Maka nilai koefisien determinasi karena adanya interaksi teknologi informasi dengan kemampuan pengguna sebagai variable moderasi adalah sebesar 90,5\%. Dapat disimpulkan bahwa kinerja pegawai dipengaruhi oleh teknologi informasi dan moderasi kemampuan pengguna sebesar 90,5\%, sedangkan sisanya sebesar $9,5 \%$ dijelaskan oleh faktor-faktor lain yang tidak dimasukkan ke dalam penelitian ini.

Pengaruh Penerapan Teknologi Informasi terhadap Kinerja Pegawai

Hasil pengujian hipotesis pertama berpengaruh positif dan signifikan teknologi informasi terhadap kinerja pegawai. Berdasarkan penelitian yang telah dilakukan menurut hasil pengujian maka dapat disimpulkan bahwa dengan adanya penerapan teknologi informasi di dalam sebuah organisasi atau perusahaan dapat mempengaruhi tingkat kinerja pegawai atau dengan kata lain apabila sebuah kantor kecamatan malili menerapkan teknologi informasi maka dapat meningkatkan kinerja pegawai yang bersangkutan dan sebaliknya, meskipun dalam penelitian tersebut menyebutkan bahwa variabel penerapan teknologi informasi bukan menjadi faktor utama yang mempengaruhi tingkat kinerja pegawai karena masih terdapat faktor-faktor lain yang dapat mempengaruhinya. Penelitian ini dilakukan di kantor kecamatan malili sehingga dapat dikatakan bahwa penerapan teknologi informasi di kantor kecamatan malili memiliki pengaruh positif terhadap peningkatan kinerja pegawai yang bersangkutan. Dengan kata lain tujuan mengenai penggunaan teknologi informasi guna meningkatkan kinerja pegawai dan pelayanan dapat dikatakan sangat tepat. Sehubungan dengan hasil penelitian hipotesis pertama yang hasilnya berpengaruh positif signifikan, maka disimpulkan semakin baik penerapan teknologi informasi di kantor kecamatan malili maka akan semakin baik pula kinerja pegawainya sesuai yang diinginkan.

Pengaruh Kemampuan Pengguna Terhadap Kinerja Pegawai

Hasil pengujian hipotesis kedua menunjukkan bahwa kemampuan pengguna berpengaruh positif signifikan terhadap kinerja pegawai. Berdasarkan penelitian yang telah dilakukan menurut hasil pengujian 
maka dapat disimpulkan bahwa dengan adanya kemampuan pengguna di dalam sebuah organisasi atau perusahaan dapat mempengaruhi tingkat kinerja pegawai atau dengan kata lain apabila sebuah kantor kecamatan malili menerapkan pelatihan kemampuan pengguna maka dapat meningkatkan kinerja pegawai yang bersangkutan dan sebaliknya, meskipun dalam penelitian tersebut menyebutkan bahwa variabel penerapan kemampuan pengguna bukan menjadi faktor utama yang mempengaruhi tingkat kinerja pegawai karena masih terdapat faktor-faktor lain yang dapat mempengaruhinya. Penelitian ini menunjukkan bahwa peningkatan kemampuan pengguna dalam kinerja pegawai pada kantor kecamatan malili dapatpdicapai apabilapkemampuan yang menyangkut pengetahuan dan keterampilan dari para pengguna sistem informasi semakin dikembangkan. Kemampuan pengguna dalam sistem teknologi informasi berkaitan dengan kapasitas individu dalam penggunaan sistem teknologi informasi untuk mengerjakan berbagai tugas dalam suatu pekerjaan sesuai dengan tanggung jawab yang dipercayakan. Kemampuan pengguna dalam sistem teknologi informasi di antaranya pengetahuan pengguna mengenai sistem teknologi informasi, pemahaman terhadap tugas dan pekerjaan sebagai pengguna sistem, mampu menjalankan sistem yang ada, serta mampu mengerjakan tugas dan pekerjaan yang menjadi tanggung jawab pegawai kantor Kecamatan Malili.

Pengaruh Penerapan Teknologi Informasi Terhadap Kinerja Pegawai dan Kemampuan Pengguna Sebagai Veriabel Moderasi.

Dari hasil penelitian menunjukkan sebelum adanya moderasi memiliki nilai nilai adjusted $\mathrm{R}$ squarePsebesar $0.860(86,0 \%)$ hal ini memberikan hasil bahwa terjadi peningkatan nilai adjusted $\mathrm{R}$ square dari regresi sebelumadanya moderasi $0.860(86,0 \%)$ ke regresi setelah adanya moderasi $0.905(90,5 \%)$ dengan demikian dapat disimpulkan bahwa keberadaan kemampuan pengguna sebagai variabel moderasi dapat memoderasi dengan memperkuat atau meningkatkan pengaruh variabel penerapan teknologi informasi terhadap variabel kinerja pegawai. Dalam uji hipotesis ketiga tabel koefisien juga diperoleh persamaan, yaitu:

$$
\mathrm{Y}=2.180+1.216+1.602+0,197 \mathrm{X} 1 * \mathrm{X} 2+\mathrm{e}
$$

Dari persamaan tersebut menunjukkan variable kinerja pegawai secara konstan bernilai 2.180, koefisien penerapan teknologi informasi (X1) sebesar 1.216 berarti penerapan teknologi informasi berpengaruh positif dan signifikan terhadap kinerja pegaawai setelah adanya variabel moderasi, koefisien kemampuan pengguna sebesar 1.602 yang artinya kemampuan pengguna (X2) berpengaruh positif dan signifikan terhadap kinerja pegawai setelah adanya variable moderasi, dan koefisien moderasi $(\mathrm{X} 1 * \mathrm{X} 2)$ sebesar 0,197 diartikan bahwa variable moderasi berpengaruh positif dan signifikan terhadap kinerja pegawai, sehingga dapat dikatakan bahwa kemampuan pengguna dapat memoderasi hubungan antara penerapan teknologi informasi dan kinerja pegawai dan signifikan karena nilai signifikansi lebih kecil dari 0,05. Hasil uji regresi pada tabel uji Anova menunjukkan hasil (sig 0.00) yang artinya lebih kecil dari 0,50 jadi dapat dikatakan bahwa model regresi ini dapat dipakai untuk memprediksi variabel kinerja pegawai atau secara bersama-sama (simultan) mempengaruhi kinerja pegawai. Jadi disimpulkan bahwa variabel kemampuan pengguna sebagai variabel moderasi bisa dijadikan variable independen pada penelitian ini. Berdasarkan uji hipotesis ketiga juga dibuktikan bahwa seorang pegawai yang menggunakan teknologi informasi harus mempunyai kemampuan pengguna yang baik. Dari hasil penelitian menujukkan kemampuan pengguna mempunyai pengaruh terhadap hubungan antara penerapan teknologi informasi dan kinerja pegawai secara signifikan.

\section{KESIMPULAN DAN SARAN}

Hasil penelitian dan pembahasan dapat disimpulkan bahwa teknologi informasi berpengaruh positif dan signifikan terhadap kinerja pegawai, dimana semakin baik teknologi yang ada disuatu kantor maka kinerja pegawai akan semakin meningkat. Hasil uji statistik maka dapat disimpulkan bahwa kemampuan pengguna berpengaruh positif dan signifikan terhadap kinerja pegawai, hal ini berarti bahwa apabila suatu pegawai semakin ditingkatkan kompetensinya dalam hal bidangnya maka kinerja suatu pegawai juga akan semakin meningkat. Dari hasil persamaan regresi untuk mengukur variabel moderasi kemampuan pengguna terhadap pengaruh teknologi informasi terhadap kinerja pegawai, maka dapat disimpulkan bahwa variabel moderasi mempunyai pengaruh positif dan signifikan terhadap pengaruh teknologi informasi terhadap kinerja pegawai, dapat dilihat dari adanya terjadi peningkatan dari sebelum moderasi ke setelah moderasi.

\section{DAFTAR PUSTAKA}

Alma. 2007. Manajemen Pemasaran dan Pemasaran Jasa. Edisi Revisi. Bandung.

Afdaliana, A., Saleh, M. Y., \& Sapiri, M. (2019). Analisis Sumber Dan Penggunaan Dana Berbasisteknologi Digital Terhadap Profitabilitas Studi Kasus Pada Pt Bank Rakyat Indonesia (Persero) Tbk Kantor Cabang Makassar Panakkukang. Indonesian Journal of Business and Management, 1(2), 1-8. https://doi.org/10.35965/jbm.v1i2.229

Alim, S., \& Rakhmat, H. A. B. (2020). The Construction of Academic Optimism Scale (AOS) to Describe Optimism in Educational Setting. Ecosystem, 20, 199-206.

Dewi, Fany Rengganis. (2015). Pengaruh Penggunaan Teknologi Informasi Terhadap Kinerja Auditor". Skripsi Sarjana Universitas Diponegoro Semarang.

Ghozali, Imam. (2012). Aplikasi Analisis Multivariate Dengan Program IBM SPSS. Penerbit. Universitas Diponegoro. Semarang.

Kadir, Abdul \& Triwahyuni Terra Ch (2013). 
Pengantar Teknologi Informasi Edisi Revisi. Penerbit CV Andi Offset. Yogyakarta

Malayu Hasibuan, SP. (2013). Manajemen Sumber Daya Manusia Edisi Revisi. Penerbit. Bumi Aksara. Jakarta. Hlm: 94.

Sugiyono. (2012). Metode Untuk Bisnis. Penerbit. Alfabet.

Sugiyono. (2013). Statistika Untuk Penelitian. Penerbit. Tarsito. Bandung.

Sugiyono. (2014). Metodep Penelitian Kuantitatif Kualitatif. Penerbit. Alfabeta. Bandung.Hlm: 6-7.

Yoga Putu Artanaya, Dan Ketut Yadnyana. (2016). Pengaruh Partisipasi Pemakai Terhadap Kinerja Sistem Informasi Akuntansi Dengan Kemampuan Pemakai Sebagai Variabel Moderasi. Jurnal Akuntansi, Vol 15 No 2

Rahmawati, Sarah Aulia, (2015). Pengaruh Partisipasi Pengguna Sistem Informasi Dan Kemampuan Pengguna Sistem Informasi Terhadap Kinerja Sistem Informasi Akuntansi, Jurnal Internal Universitas Telkom Vol.2

Utami, Shendy Cahyaning, Dewi Saptantinah Puji Astuti. Dkk (2016). Pengaruh Kemampuan Pengguna Sistem Informasi, Keterlibatan Pengguna Dan Dukungan Manajemen Puncak Terhadap Kinerja Sistem Informasi Akuntasi Pada PT BTPN Area Surakarta. Jurnal Akuntansi Dan Sistem Informasi Vol. 12 No. 2 Hlm : 208-220

Ratnasari, Komang Septi, Edy Sujana Dkk. (2012). Pengaruh Kecanggihan Teknologi Informasi, Pertisipasi Pengguna Dan Kemampuan Pengguna Terhadap Kinerja Sistem Informasi Akuntansi Pt Pln Area Bali Utara. E-Jurnal. Vol.7, No.1.

Peraturan Bupati Luwu Timur Nomor 47 Tahun 2017 Tentang Pemanfattan Teknologi Informasi Dan Komunikasi Dalam Pengembangan E-Government Dilingkungan Pemerintah Kabupaten Luwu Tim 